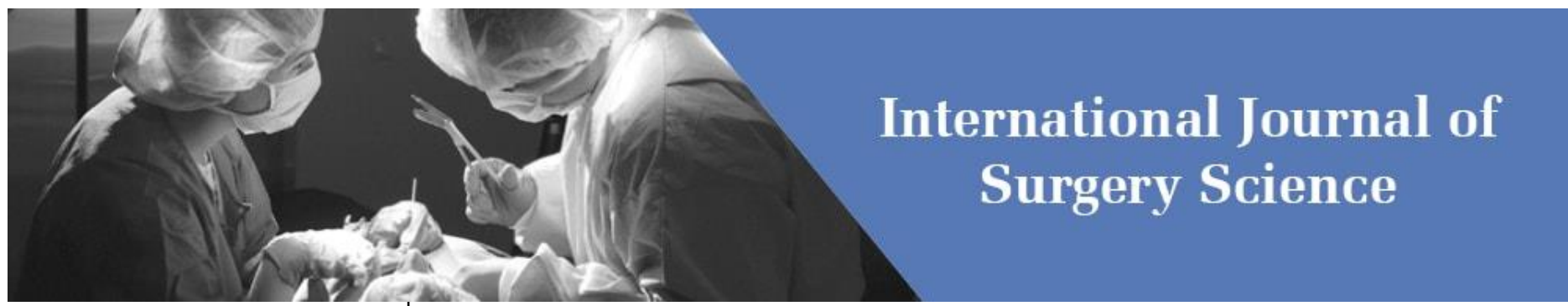

E-ISSN: 2616-3470

P-ISSN: 2616-3462

(C) Surgery Science

www.surgeryscience.com

2019; 3(4): 209-216

Received: 09-08-2019

Accepted: 13-09-2019

Dr. Honeypalsinh $\mathbf{H}$

Associate Professor, Maharaul,

Department of Surgery, Sbksmirc,

Sumandeep Vidyapeeth, Pipariya,

Vadodara, Gujarat, India

Dr. Tirthkumar Joshi

Resident, Department of Surgery,

Sbksmirc, Sumandeep Vidyapeeth,

Pipariya, Vadodara, Gujarat, India

Dr. Aakash Rajshakha

Senior Resident, Department of

Surgery, Sbksmirc, Sumandeep

Vidyapeeth, Pipariya, Vadodara,

Gujarat, India
Corresponding Author:

Dr. Honeypalsinh $\mathbf{H}$

Associate Professor, Maharaul,

Department of Surgery, Sbksmirc,

Sumandeep Vidyapeeth, Pipariya,

Vadodara, Gujarat, India

\section{Effect of honey impregnated dressing v/s silver sulfadiazine in healing of chronic ulcer and burns}

\section{Dr. Honeypalsinh H, Dr. Tirthkumar Joshi and Dr. Aakash Rajshakha}

DOI: https://doi.org/10.33545/surgery.2019.v3.i4d.242

\section{Abstract}

Introduct209-21ion: The exact number of wound cases is difficult to determine; however, in a country like India, with a population of over 1 billion, there are around 700,000-800,000 burn admissions per year. With availability of various products for dressing this study intends to compare honey dressing v/s silver sulfadiazine at our institute.

Materials and Methods:

Type of study: Prospective Observational

Study design: Cross Sectional Study

Study population:

- $\quad$ Age: more than 18 years

- Gender: Both male \& female

Study duration: 12 Months

Study centre: Department of Surgery, Dhiraj General Hospital

Study sample size: In present study, we have enrolled total 40 patients.

Results: Out of total 40 patients $57.50 \%$ were male and $42.50 \%$ were female and all the patients were divided into two groups i.e. Honey group and SSD group. Mean age of all the enrolled participants was $59.91 \pm 9.89$ years. Mean healing days required was significantly less in honey group compare to mean healing days required in SSD group, i.e. $12.47 \pm 4.15$ vs. $15.78 \pm 5.78$. We found $\mathrm{p}$ value was 0.000 which is highly significant.

Conclusion: Honey dressings is superior to Silver sulfadiazine (SSD) in chronic ulcer and burns, in terms of decreased morbidity, economy, patient well-being and speedy rehabilitation.

Keywords: Honey dressing, silver sulfadiazine, wound, burns

\section{Introduction}

The exact number of wound cases is difficult to determine; however, in a country like India, with a population of over 1 billion, there are around 700,000-800,000 burn admissions per year. [1] Wound injuries to the skin result in loss of its protective function as a barrier to microorganisms leading to the high risk of infection. Thus, patients with wound face high morbidity than mortality because of the large uncovered skin surface getting infected, healing of which takes long periods of dressings, leading to deformities and contractures ${ }^{[2]}$. Unfortunately, the management of the wounds still remains a matter of debate and an ideal dressing for various wounds has not been discovered. ${ }^{[2]}$ Moreover, in developing countries, wound management is riddled with difficulties.

The utilization of topical chemotherapy has been key in such manner and has enhanced the survival of patients with real consumes and to limit the frequency of consume wound sepsis, a main source of mortality and bleakness in these patients ${ }^{[2]}$. One of the methodologies that is increasing recharged consideration for fighting the danger of bacterial contamination and averting wound sepsis, is the utilization of honorable metal antimicrobials the most predominant of which is silver ${ }^{[3]}$. For a considerable length of time silver has been known to have bactericidal properties. As right on time as 1000 B.C., the antimicrobial properties of silver in rendering water consumable were acknowledged ${ }^{[4,5]}$. Silver mixes have been abused for their restorative properties for quite a long time too ${ }^{[6]}$. They were mainstream solutions for lockjaw and stiffness in the nineteenth century and for colds and gonorrhea before the coming of antiinfection agents in the early piece of the twentieth century ${ }^{[7]}$. A definite verifiable survey about the early utilization of silver to treat different conditions has been as of late distributed ${ }^{[8]}$. 
Enthusiasm for silver salts or silver salt arrangements in the treatment of consume patients, be that as it may, totally vanished around the Second World War [9]. It took numerous years for enthusiasm for silver (nitrate) to restore, under the jolt of a production by Moyer et al. ${ }^{[10]}$. At present, silver has reemerged as a feasible treatment choice for diseases experienced in consumes, open injuries, and chronic ulcers.

Several Products have incorporate silver for use as a topical antibacterial specialist, for example, silver nitrate, silver sulphadiazine (SSD) (FlammazineTM, Smith and Nephew Healthcare Limited, Hull, Canada) [11], silver sulphadiazine/chlorhexidine (Silverex1, Motiff Laboratories Pvt. Ltd. Kare Health fortes, Verna, Goa), SSD with cerium nitrate (Flammacerium1, Solvay, Brussels, Belgium), and silver sulphadiazine impregnated lipidocolloid wound dressing Urgotul SSD1 (Laboratories Urgo, Chenove, France) ${ }^{[5,11-13]}$. As opposed to these silver operators, recently created items, for example, ActicoatTM (Westaim Biomedical Inc., Fort Saskatchewan, Alberta, Canada) and Silverlon1 (Argentum Medical, L.L.C., Lakemont, Georgia) have a more controlled and delayed arrival of nanocrystalline silver to the injury region. This method of silver conveyance enables the dressings to be changed with less recurrence, along these lines diminishing danger of nosocomial contamination, cost of care, additionally tissue harm and patient distress ${ }^{[4,14-16]}$.

The best quality level in topical consume treatment is silver sulfadiazine (Ag-SD), a helpful antibacterial specialist for consume wound treatment. Late discoveries, notwithstanding, demonstrate that the compound postpones the injury recuperating process [17] and that silver may have genuine cytotoxic movement on different host cells ${ }^{[2,17-22]}$. Then again, the useful impacts of silver on wound science because of its intense antimicrobial movement have been disregarded as a rule as of not long ago. The writing is getting to be plainly loaded with clinical trials implying to demonstrate the advantages of silver therapeutics and silver-discharge dressings on wound repair and recovery through its antimicrobial viability. Little is distributed, in any case, to demonstrate how the discharged silver particle impacts the injury bed, or to what degree it is utilized or saved in the tissue. Also, consequences of the broad writing audit we led neglected to uncover any clinical examinations in regards to the dangers and probabilities of wounds as a rule to end up noticeably tainted, about the impact of silver dressings on officially contaminated injuries, nor about investigations contrasting the impact of silver or other germicide dressings on aversion of wound disease.

Regardless of the source of silver, whether discharged from arrangements, creams and salves or nanocrystalline silver discharged from economically accessible new dressings, silver is profoundly harmful to both keratinocytes and fibroblasts [23]. Fibroblasts give off an impression of being more touchy to silver than keratinocytes. Thought of the cytotoxic impacts of silver and silver-based items ought to be taken when settling on dressings for particular injury mind procedures. This is especially vital when utilizing keratinocyte culture, in situ, which is assuming an expanding part in contemporary injury and consume mind ${ }^{[23,24]}$. Also, certain current clinical investigations in significant consume focuses have exhibited the rise of bacterial safe strains basically Escherichia coli, to silver and to numerous anti-microbials following the delayed use of silver based dressings. The present survey goes for looking at all accessible confirmation about impacts, frequently conflicting, of silver on wound disease control and on wound recuperating attempting to decide the pragmatic helpful harmony between antimicrobial action and cell poisonous quality.

Honey has for some time been recorded as having recuperating properties ${ }^{[27-29]}$. Honey and sugar paste were related with scarless mending in cavity wounds ${ }^{[30]}$. It has been accounted for that rabbit wounds treated with a topical utilization of Honey indicated less edema, less polymorphonuclear and mononuclear cell penetrations, less rot, better wound constriction, enhanced epithelialization, and lower glycosaminoglycan and proteoglycan concentrations [31]. Besides, Honey causes essentially more noteworthy injury compression than controls, and it advances the development of granulation tissue and epithelialization of wounds [32-37]. Honey fortifies tissue development, combination of collagen, and improvement of fresh recruit's vessels in the bed of wounds ${ }^{[38-43]}$. Intraperitoneal Honey organization after a bond demonstrate in the cecum and terminal ileum of rats decreased postoperative adhesion ${ }^{[44]}$.

For the most part, wound healing can be influenced by endogenous (pathophysiology) and exogenous (microorganisms) factors. The danger of wound contamination increments as neighborhood conditions support bacterial intrusion and development. Accordingly, microbial colonization of both intense and interminable injuries is inescapable. Numerous types of microbes have been recouped from wounds, yet Staphylococcus aureus is the most much of the time detached from wound pathogens ${ }^{[45]}$. What's more, Pseudomonas aeruginosa is a vital pathogen in perpetual injuries and consumes; its quality has been exhibited in various examinations and has been found in one third of unending leg ulcers ${ }^{[46-49]}$. Contamination with S. aureus and pseudomonads impedes ulcer recuperating rates and, with pseudomonads and B-hemolytic streptococcus, decreases the achievement of skin joins utilized for leg ulcers ${ }^{[50,51]}$. The across the board improvement of antiinfection safe microscopic organisms is a testing issue.

This study intends to compare honey dressing $\mathrm{v} / \mathrm{s}$ silver sulfadiazine at our institute.

\section{Aims}

- To review and study patients who presented with chronic ulcer and burns and to study the effect of honey dressing on such wounds.

\section{Objectives}

1. To study the effects of honey on wound with respect to its hygroscopic action, bactericidal action.

2. To study the effect of honey on wound healing time and compare with silver sulfadiazine.

3. To study complications of honey dressing.

\section{Material and Methods \\ Type of study: Prospective Observational \\ Study design: Cross Sectional Study \\ Study population}

- Age: more than 18 years

- Gender: Both male \& female

Study duration: 12 Months

Study centre: Department of Surgery, Dhiraj General Hospital

Study sample size: In present study we have enrolled total 40 patients.

\section{Inclusion criteria}

- All the patients referred to or admitted under the departments of general Surgery and diagnosed to have chronic wound either infected or burns. 


\section{Exclusion criteria}

- Patient not willing for study.

- Patient with immunocompromised status, comorbid factors like cardiac / respiratory diseases, organ failure and on chemotherapy were excluded.

\section{Method of collection of data}

All the patient presenting with chronic wound in surgery outpatient department or casualty were screened for the study and then study related procedure were explained to them by the investigator in presence of LAR and impartial witness if required and gave sufficient time to patient and relative to understand the procedure then after if patient and LAR gave consent to participate in the study then only we enrolled the patient in the study. After enrolling the patient in the study all details of them were taken. On admission history was collected and thorough physical examination done. Data collection on admission included age, sex, address and clinical presentation with respect to site /size/ onset duration and progress of wound.
History of probable aetiology with respect to trauma, diabetes, tuberculosis, varicose veins will be noted.

History of previous episodes and co-morbidities was noted. Clinical examination of wound/ulcer was done as described in Proforma. Routine investigations like complete hemogram, Blood urea, and Random blood sugar were performed.

The treatment plan was focused on adequate control of infections and control of blood sugar. Wound debridement if required to be done followed by closed dressing with honey / Silver Sulfadiazine and gauze pad. Serial dressing of the wound was done and healing of the wound in the form of granulation tissue formation, reduction in the size of wound, contraction of the wound and time taken was noted every 2 weeks. Data like clinical symptoms and signs, results of investigations, complications, surgical procedures if any, duration of hospital stay was recorded.

\section{Results and Discussion}

\section{Comparison of gender distribution}

Table 1: Comparison of Gender Distribution

\begin{tabular}{|c|c|c|c|c|}
\hline Gender & Present study & \% & Memon et al & \% \\
\hline Male & 23 & $57.50 \%$ & 37 & $61.67 \%$ \\
\hline Female & 17 & $42.50 \%$ & 23 & $38.33 \%$ \\
\hline Total & 40 & $100.00 \%$ & 60 & $100.00 \%$ \\
\hline
\end{tabular}

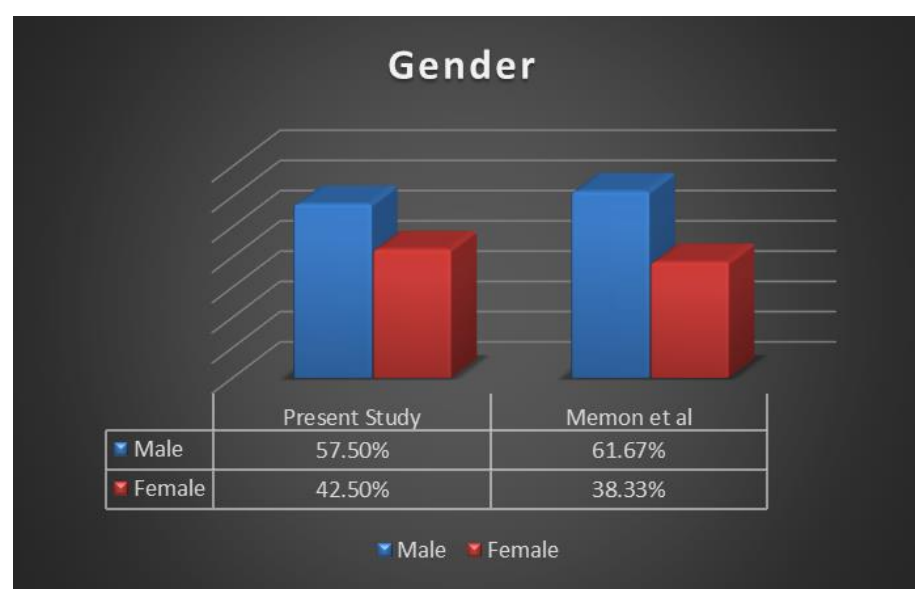

Graph 1: Comparison of Gender Distribution

- We have compared number of patients enrolled in present study with the study done by Memon et al and we have found that in Memon et al study there were total 60 patients enrolled and in the present study we have enrolled 40 patients.

- Furthermore, we also compared the gender distribution in both the study but we found the consistent results of present study with Memon et study. In Memon et al study percentage of male patients were higher compared to female patients but it was not statistically significant whereas in present study also percentage of male patients were higher but again it was not statistically significant.

- Male predominance was found in both studies may be attributed to those population working at risk areas more prone to trauma and other injuries.

- Female population in our country are mainly housewives and have to cook food mainly by burning traditional chulas as India is a developing country. Thus, making these population vulnerable to burn injury.

\section{Comparison of age group distribution}

Table 2: Comparison of Age Group Distribution

\begin{tabular}{|c|c|c|c|c|c|c|}
\hline Age Distribution & Present Study & \% & Memon et al. & \% & Malik et al. & \% \\
\hline $21-30$ & 3 & $7.50 \%$ & 4 & $6.67 \%$ & 17 & $11.33 \%$ \\
\hline $31-40$ & 5 & $12.50 \%$ & 7 & $11.67 \%$ & 20 & $13.33 \%$ \\
\hline $41-50$ & 7 & $17.50 \%$ & 12 & $20.00 \%$ & 34 & $22.67 \%$ \\
\hline $51-60$ & 10 & $25.00 \%$ & 21 & $35.00 \%$ & 39 & $26.00 \%$ \\
\hline$>61$ & 15 & $37.50 \%$ & 26 & $43.33 \%$ & 40 & $26.67 \%$ \\
\hline Total & 40 & $100.00 \%$ & 60 & $100.00 \%$ & 150 & $100.00 \%$ \\
\hline
\end{tabular}




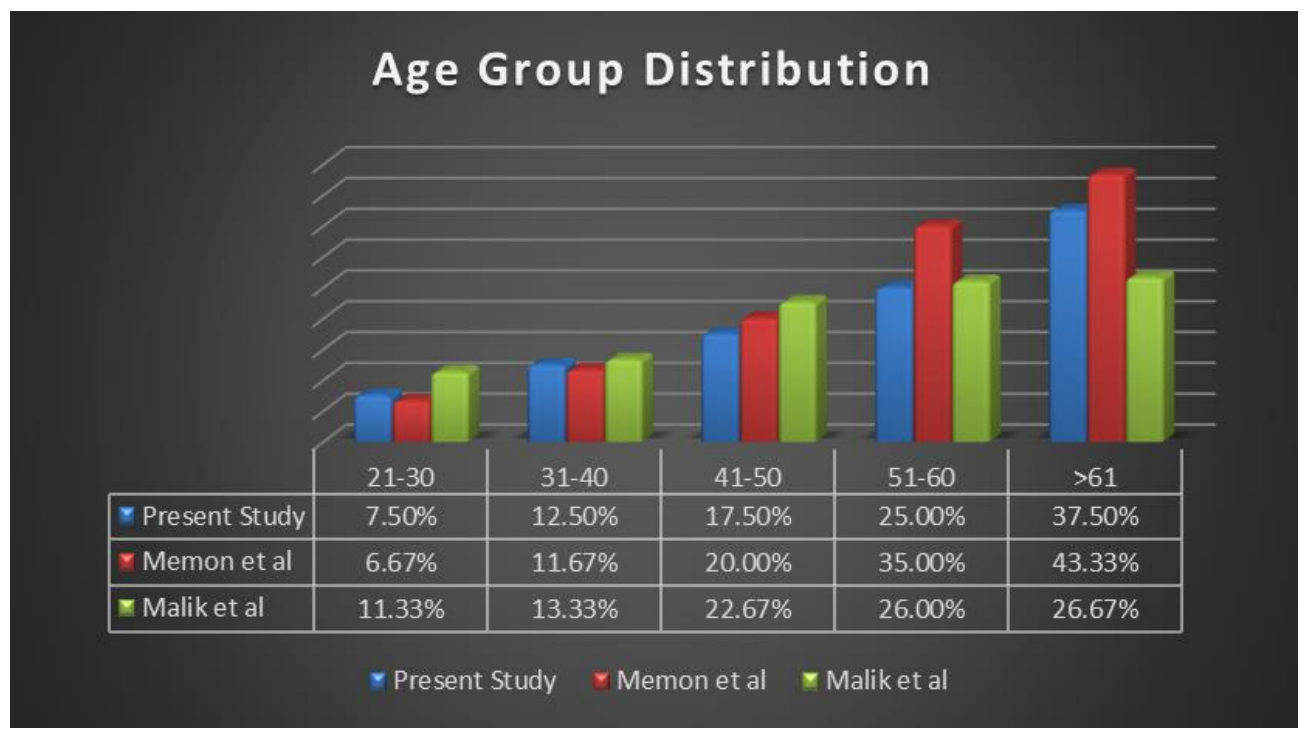

Graph 2: Comparison of age group distribution

- In above table and graph we have shown the comparison of different age groups of present study with two other studies, i.e. Memon et al and Malik et al.

- In Memon et al and Malik et al study they have majority of patients with age of more than 50 years which is similar to present study.

- In Memon et al study more than $75 \%$ of patients were falls in age group of more than 50 years.

- In Malik study, more than $50 \%$ of the patients were of more than 50 years.

- We observed that our results were similar with both the studies.
- In present study, majority patients $(62.50 \%)$ who enrolled in the study were had age more than 50 years.

- Wound healing time is reduced as the age progresses and the population above the age of 50 years are having comorbid conditions like hypertension, diabetes, peripheral vascular disease like atherosclerosis, thus presents with chronic wound.

- In the modern world, these population are not taken care of by their children's and abandoned thus neglects early and small wound.

\section{Comparison of mean age of the patients}

Table 3: Comparison of mean age of the patients

\begin{tabular}{|c|c|c|c|c|c|c|}
\hline Gender & Mean Age (Present Study) & SD & Mean Age (Memon et al) & SD & Mean Age (Malik et al) & SD \\
\hline Male & 60.04 & 9.45 & 63.34 & 10.56 & 61.34 & 12.45 \\
\hline Female & 59.78 & 10.34 & 60.34 & 11.34 & 59.45 & 11.23 \\
\hline Total & 59.91 & 9.89 & 61.84 & 10.95 & 60.40 & 11.84 \\
\hline
\end{tabular}

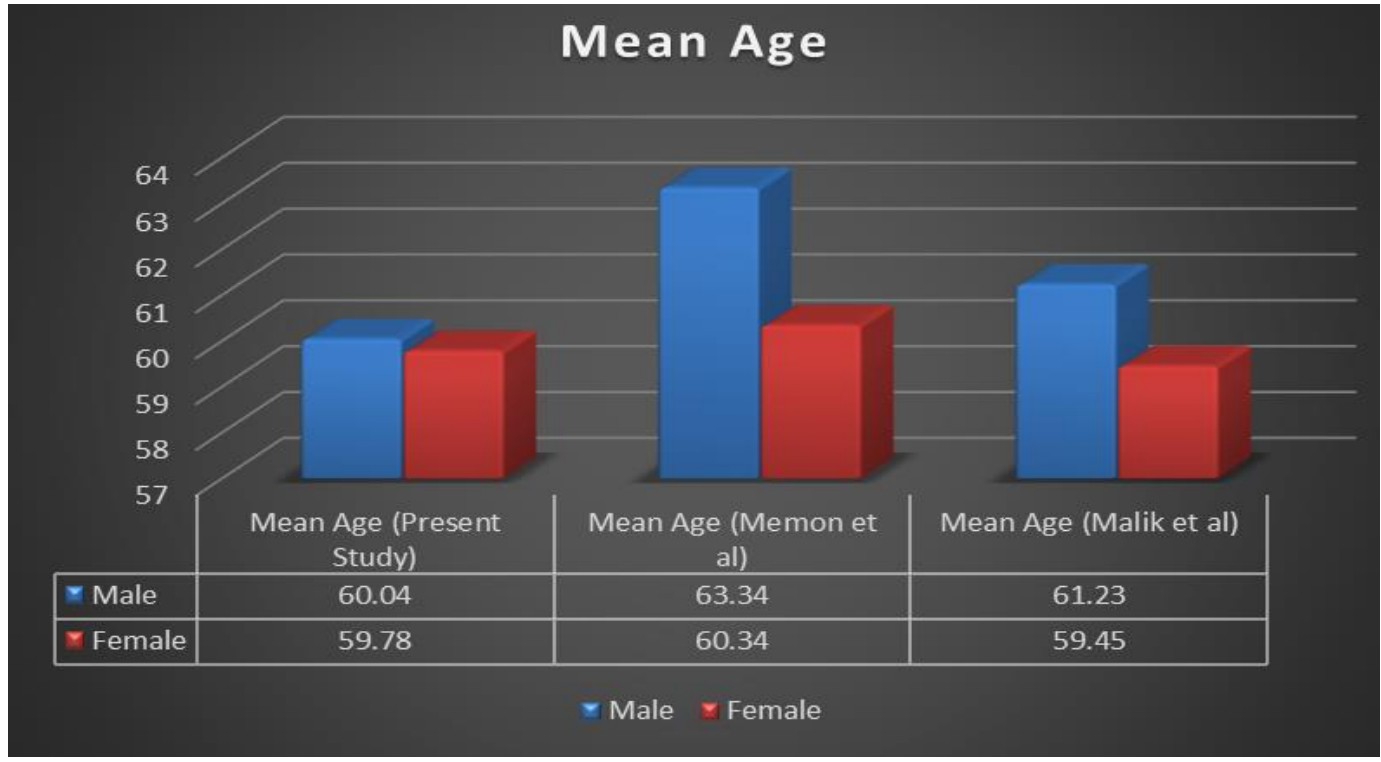

Graph 3: Comparison of mean age of the patients

- In above table and graph we have shown the comparison of mean age of present study with two other studies, i.e. Memon et al and Malik et al. And we have found that our results were similar with both the studies.

- In Memon et al and Malik et al study they had patients with mean age $61.84 \pm 10.95$ years and $60.40 \pm 11.84$ which is 
similar to present study, i.e. $59.91 \pm 9.89$.

- Furthermore we have compared mean age of both gender of present study with Memon et al study and Malik et al study and we have found that in all three studies including present study age of male patients is slightly higher compare to female patients so, this results were also consistent with other studies.

- In Memon et al study mean age of male was $63.34 \pm 10.56$ years and mean age of female patients was $60.34 \pm 11.34$ years where as in Malik study mean age of male patients was $61.23 \pm 12.45$ years and mean age of female patients was $59.45 \pm 11.23$ years all these results we found similar in present study i.e. mean age of male patients of present study was $60.04 \pm 9.45$ years and mean age of female patients was $59.78 \pm 10.34$ years.

\section{Comparison of average healing days}

Table 4: Comparison of average healing days

\begin{tabular}{|c|c|c|c|c|c|c|}
\hline \multicolumn{7}{|c|}{ Mean Healing Days } \\
\hline Group & Present Study & SD & Memon et al study & SD & Malik et al study & SD \\
\hline Honey & 12.47 & 4.15 & 13.23 & 4.32 & 11.67 & 7.12 \\
\hline SSD & 15.78 & 5.78 & 16.32 & 6.56 & 15.45 & 6.89 \\
\hline Total & 14.12 & 4.96 & 14.72 & 5.23 & 13.45 & 7.03 \\
\hline
\end{tabular}

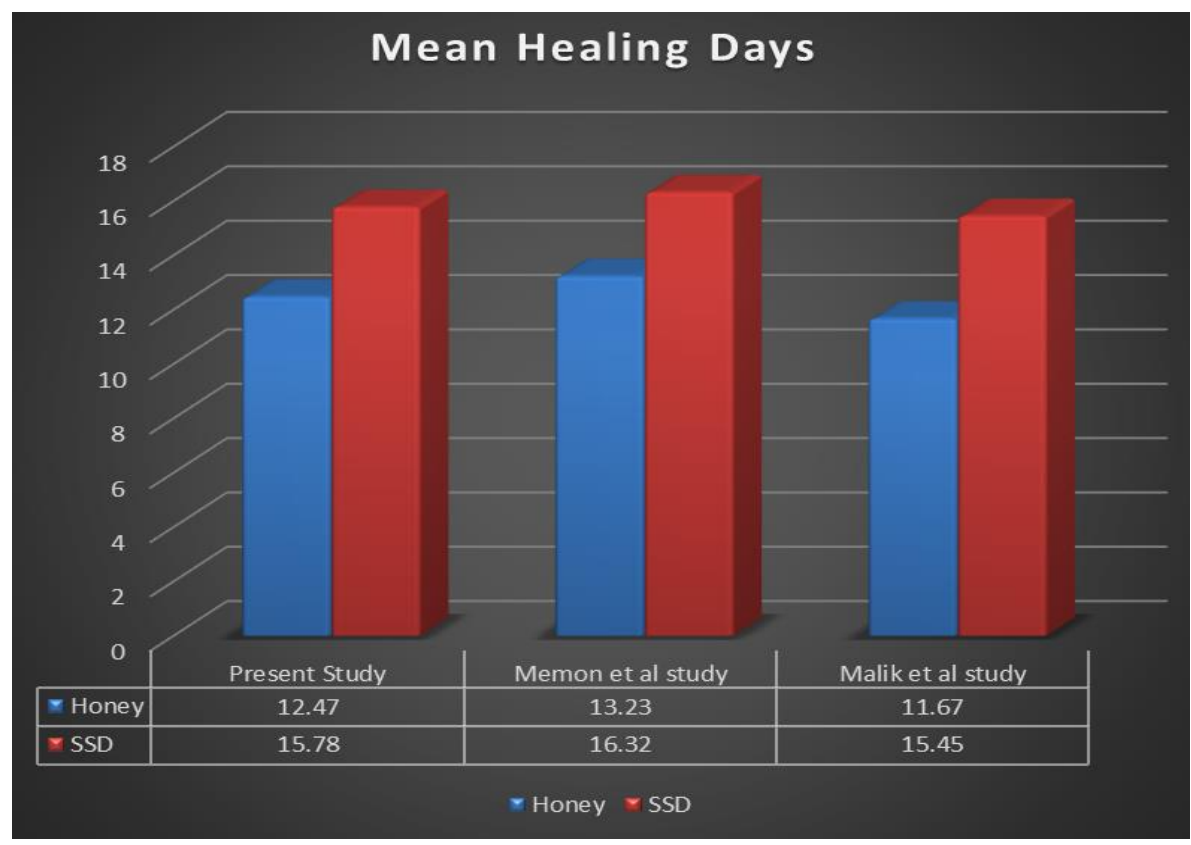

Graph 4: Comparison of average healing days

- In above table and graph we have shown the comparison of average healing days required in present study with two other studies and we have found similar results with both the studies.

- Mean healing days in Memon et al study was $14.72 \pm 5.23$ days where as in Malik et al study they have noted mean healing day was $13.45 \pm 7.03$ days and in present study we have found mean healing day was $14.12 \pm 4.96$ days.

- Furthermore, we have compared our results of comparison of mean healing days required in Honey Group and SSD group with both the study and we found that in honey group significant fewer days are required for healing compare to SSD group in all three studies including present study.

- In Memon et al study Mean healing days required in honey group was 13.23 \pm 4.32 days and in SSD group 16.32 \pm 6.56 days.

- In Malik et al study Mean healing days required in honey group was $11.67 \pm 7.12$ days and in SSD group 15.45 \pm 6.89 days.

- In Present Study Mean healing days required in honey group were $12.47 \pm 4.15$ days and in SSD group $15.78 \pm 5.78$ days.

- $\quad$ In all three-studies $\mathrm{p}$ value was 0.000 .

- Thus, healing time with honey impregnated dressing is less than Silver Sulfadiazine (SSD).

\section{Comparison of time for complete healing}

Table 5: Comparison of time for complete healing

\begin{tabular}{|c|c|c|c|c|c|c|c|c|c|c|c|c|}
\hline \multirow{2}{*}{$\begin{array}{c}\text { Time for Compete } \\
\text { Healing }\end{array}$} & \multicolumn{4}{|c|}{ Present Study } & \multicolumn{4}{|c|}{ Memon et al Study } & \multicolumn{4}{|c|}{ Malik et al Study } \\
\hline & Honey & $\%$ & SSD & $\%$ & Honey & $\%$ & SSD & $\%$ & Honey & $\%$ & SSD & $\%$ \\
\hline$<10$ Days & 6 & $30.00 \%$ & 1 & $5.00 \%$ & 7 & $23.33 \%$ & 2 & $6.67 \%$ & 30 & $20.00 \%$ & 13 & $8.67 \%$ \\
\hline 11-15 Days & 8 & $40.00 \%$ & 4 & $20.00 \%$ & 12 & $40.00 \%$ & 8 & $26.67 \%$ & 92 & $61.33 \%$ & 67 & $44.67 \%$ \\
\hline 16-20 Days & 4 & $20.00 \%$ & 7 & $35.00 \%$ & 9 & $30.00 \%$ & 5 & $16.67 \%$ & 18 & $12.00 \%$ & 10 & $6.67 \%$ \\
\hline 21-25 Days & 2 & $10.00 \%$ & 5 & $25.00 \%$ & 2 & $6.67 \%$ & 11 & $36.67 \%$ & 2 & $1.33 \%$ & 21 & $14.00 \%$ \\
\hline$>25$ Days & 0 & $0.00 \%$ & 1 & $5.00 \%$ & 0 & $0.00 \%$ & 4 & $13.33 \%$ & 0 & $0.00 \%$ & 10 & $6.67 \%$ \\
\hline
\end{tabular}




\section{Time for Complete Healing in Honey Group}

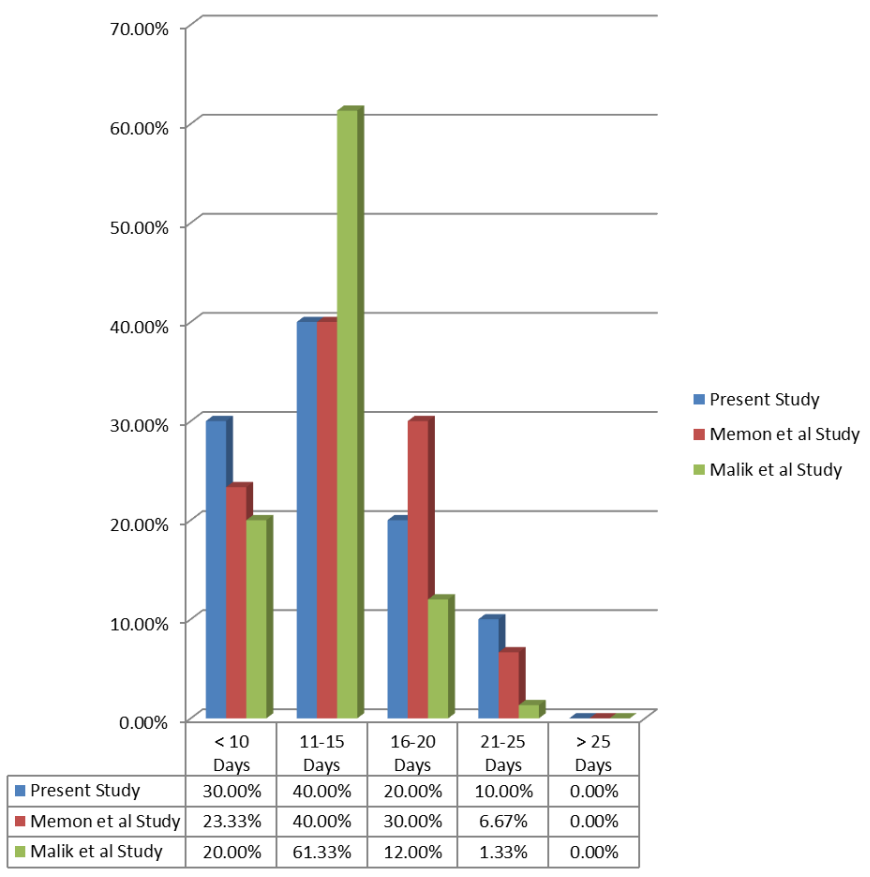

Graph 5: Time for complete healing in honey group

Time for Complete Healing (SSD Group)

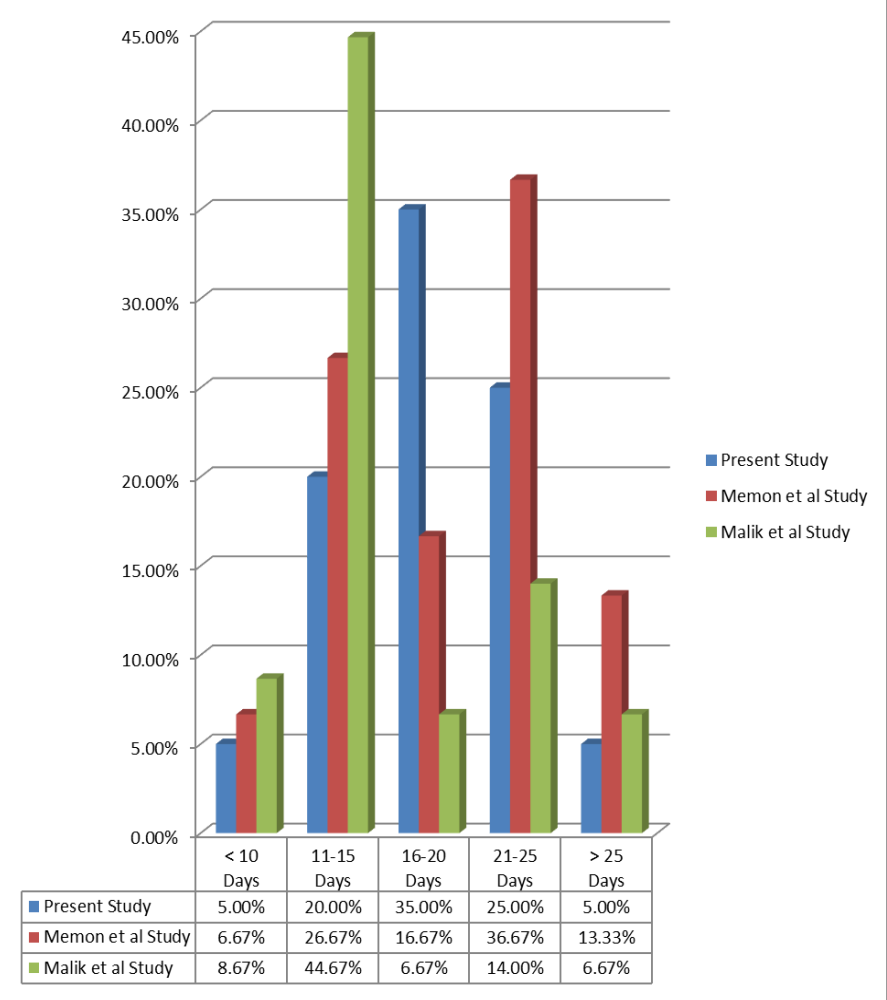

Graph 6: Time for complete healing in SSD group

- In above table and graphs, we have shown the comparison of Time for complete healing in present study with other two studies and we have found that in all three studies including present study in SSD group comparatively higher number of days required for complete healing compare to Honey group.

- In Memon et al study it was found that majority if the patients required less than 20 days for complete healing where as in SSD group there were $40 \%$ of the patients required more than 20 days compare to Honey group which required only $6.67 \%$ of patients more than 20 days in complete healing. These results were statistically significant.

- In Malik et al study it was found that majority if the patients required less than 20 days for complete healing where as in SSD group there were $20.67 \%$ of the patients required more than 20 days compare to Honey group which required only $1.33 \%$ of patients more than 20 days in complete healing. These results were statistically significant.

- In Present study, it was found that majority if the patients required less than 20 days for complete healing where as in SSD group there were $30 \%$ of the patients required more than 20 days compare to Honey group which required only $10 \%$ of patients more than 20 days in complete healing. These results were statistically significant.

- In present study, we also do comparison time required for complete healing in both gender of the both groups and we have found that in male patients more time required for healing compare to female patients and these results are statistically significant.

- We also found diabetes mellitus was common in majority of our enrolled patients, i.e. $60.00 \%$.

\section{Conclusion}

Honey dressings is superior to Silver sulfadiazine (SSD) in chronic ulcer and burns, in terms of decreased morbidity, economy, patient well-being and speedy rehabilitation.

\section{References}

1. Jaiswal AK, Aggarwal H, Solanki P, Lubana PS, Mathur RK, Odiya S. Epidemiological and socio-cultural study of burn patients in M.Y. Hospital, Indore, India. Indian J Plast Surg. 2007; 40:158-63.

2. Subrahmanyam M. Honey dressing versus boiled potato peel in the treatment of burns: A prospective randomized study. Burns. 1996; 22:491-3.

3. Gunther RT. The Greek Herbal of Dioscorides. New York: Hafner, (reprinted 1959), 1934

4. Molan PC. The antibacterial activity of honey. 1. The nature of the antibacterial activity. Bee World. 1992; 73(1):5-28.

5. Brady NF, Molan PC, Harfoot CG. The sensitivity of dermatophytes to the antimicrobial activity of manuka honey and other honey. Pharm Sci. 1997; 2:1-3.

6. Select Committee on Science and Technology. Report no. 7: Resistance to antibiotics and other antimicrobial agents. London: House of Lords, 1998.

7. Dustmann H. Antibacterial effect of honey. Apiacta 1979; 14(1):7-11.

8. Bose B. Honey or sugar in treatment of infected wounds? Lancet 1982; 1(8278):963.

9. Condon RE. Curious interaction of bugs and bees. Surgery 1993; 113(2):234-5.

10. Green AE. Wound healing properties of honey. Br J Surg 1988; 75(12):1278.

11. Keast-Butler J. Honey for necrotic malignant breast ulcers. Lancet 1980; 2(8198):809.

12. Mossel DA. Honey for necrotic breast ulcers. Lancet 1980; 2(8203):1091.

13. Seymour FI, West KS. Honey - its role in medicine. Med Times 1951; 79:104-7.

14. Somerfield SD. Honey and healing. J R Soc Med. 1991; 
84(3):179.

15. Tovey FI. Honey and healing. J R Soc Med. 1991; 84(7):447.

16. Chirife J, Herszage L, Joseph A, Kohn ES. In vitro study of bacterial growth inhibition in concentrated sugar solutions: microbiological basis for the use of sugar in treating infected wounds. Antimicrob Agents Chemother 1983; 23(5):766-73.

17. Herszage L, Montenegro JR, Joseph AL. Tratamiento de lasheridassupuradas con accargranuladocomercial. Bol Trab Soc Argent Cir. 1980; 41(21-22):315-30.

18. Efem SE. Clinical observations on the wound healing properties of honey. Br J Surg. 1988; 75(7):679-81.

19. Cavanagh D, Beazley J, Ostapowicz F. Radical operation for carcinoma of the vulva. A new approach to wound healing. J Obstet Gynaecol $\mathrm{Br}$ Commonw 1970; 77(11):1037-40.

20. Armon PJ. The use of honey in the treatment of infected wounds. Trop Doct. 1980; 10(2):91.

21. Braniki FJ. Surgery in Western Kenya. Ann R Coll Surg Engl 1981; 63:348-52.

22. Cooper RA, Molan PC, Harding KG. Antibacterial activity of honey against strains of Staphylococcus aureus from infected wounds. J R Soc Med. 1999; 92(6):283-5.

23. Sackett WG. Honey as a carrier of intestinal diseases. Bull Colorado State Univ Agric Exp Stn 1919; 252:1-18.

24. White JW, Subers MH, Schepartz AI. The identification of inhibine, the antibacterial factor in honey, as hydrogen peroxide and its origin in a honey glucose-oxidase system. Biochim Biophys Acta. 1963; 73:57-70.

25. Dold H, Du DH, Dziao ST. Nachweisantibakterieller, hitzeund lictemp find licher Hemmungsst of feInhibineim Naturhonig Bltenhonig [Detection of the antibacterial heat and light-sensitive substance in natural honey]. Z Hyg Infektionskr. 1937; 120:155-67.

26. Dold H, Witzenhausen R. Ein Verfahrenzur Beurteilung derrtlicheninhibitorischen (keimvermehrungshemmenden) Wirkung von HonigsortenverschiedenerHerkunft [Method of evaluation of the local inhibitory (antibacterial) substances of honeys from various origins]. $Z$ HygInfektionskr. 1955; 141:333-7.

27. Postmes TJ, Bosch MMC, Dutrieux R, van Baare J, Hoekstra MJ. Speeding up the healing of burns with honey. An experimental study with histological assessment of wound biopsies. In: Mizrahi A, Lensky Y, editors. Bee Products: Properties, Applications and Apitherapy. New York: Plenum Press, 1997, 27-37.

28. Hutton DJ. Treatment of pressure sores. Nurs Times. 1966; 62(46):1533-4.

29. Turner FJ. Hydrogen Peroxide and Other Oxidant Disinfectants ( $3^{\text {rd }}$ ed). Philadelphia: Lea and Febiger, 1983.

30. Saissy JM, Guignard B, Pats B, Guiavarch M, Rouvier B. Pulmonary edema after hydrogen peroxide irrigation of a war wound. Intensive Care Med. 1995; 21(3):287-8.

31. Salahudeen AK, Clark EC, Nath KA. Hydrogen peroxideinduced renal injury. A protective role for pyruvate in vitro and in vivo. J Clin Invest 1991; 88(6):1886-93.

32. Halliwell B, Cross CE. Oxygen-derived species: their relation to human disease and environmental stress. Environ Health Perspect. 1994; 102(10):5-12.

33. Bunting CM. The production of hydrogen peroxide by honey and its relevance to wound healing. MSc thesis. University of Waikato, 2001.

34. Frankel S, Robinson GE, Berenbaum MR. Antioxidant capacity and correlated characteristics of 14 unifloral honeys. J Apic Res. 1998; 37(1):27-31.

35. Burlando F. Sull'azioneterapeuticadelmielenelleustioni [The therapeutic effect of honey on burns]. Minerva Dermatol 1978; 113:699-706.

36. Kumar A, Sharma VK, Singh HP, Prakash P, Singh SP. Efficacy of some indigenous drugs in tissue repair in buffaloes. Indian Vet J 1993; 70(1):42-4.

37. Kandil A, El-Banby M, Abdel-Wahed K, Abou-Sehly G, Ezzat N. Healing effect of true floral and false non-floral honey on medical wounds. J Drug Res (Cairo) 1987; 17(12):71-5.

38. El-Banby M, Kandil A, Abou-Sehley G, El-Sherif ME, Abdel-Wahed K. Healing effect of floral honey and honey from sugar-fed bees on surgical wounds (animal model). Fourth International Conference on Apiculture in Tropical Climates, Cairo, 1989.

39. Oryan A, Zaker SR. Effects of topical application of honey on cutaneous wound healing in rabbits. Zentralbl Veterinarmed A 1998; 45(3):181-8.

40. Pruitt KM, Reiter B. Biochemistry of peroxidase system: antimicrobial effects. In: Pruitt KM, Tenovuo JO, editors. The Lactoperoxidase System: Chemistry and Biological Significance. New York: Marcel Dekker, 1985; 144-78.

41. Hyslop PA, Hinshaw DB, Scraufstatter IU, Cochrane CG, Kunz S, Vosbeck K. Hydrogen peroxide as a potent bacteriostatic antibiotic: implications for host defense. Free Radic Biol Med. 1995; 19(1):31-7.

42. Allen KL, Molan PC, Reid GM. A survey of the antibacterial activity of some New Zealand honeys. J Pharm Pharmacol 1991; 43(12):817-22.

43. Adcock D. The effect of catalase on the inhibine and peroxide values of various honeys. J Apic Res. 1962; 1:3840.

44. Bogdanov S. Characterisation of antibacterial substances in honey. Lebensm Wiss Technol. 1984; 17(2):74-6.

45. Molan PC, Russel KM. Non-peroxide antibacterial activity in some New Zealand honeys. J Apic Res 1988; 27:62-7.

46. Roth LA, Kwan S, Sporns P. Use of a disc-assay system to detect oxytetracycline residues in honey. $J$ Food Prot 1986; 49(6):436-41.

47. Abuharfeil N, Al-Oran R, Abo-Shehada M. The effect of bee honey on the proliferative activity of human B- and Tlymphocytes and the activity of phagocytes. Food AgricImmunol. 1999; 11:169-77.

48. Tonks A, Cooper RA, Price AJ, Molan PC, Jones KP. Stimulation of tnf-alpha release in monocytes by honey. Cytokine 2001; 14(4):240-2.

49. Ryan GB, Majno G. Inflammation. Michigan: Upjohn, 1977.

50. Aristotle. Historia Animalium (350 BC). Oxford: Oxford University, 1910.

51. Floris I, Prota R. Sulmieleamaro di Sardegna [Bitter honey from Sardegna]. Apic Mod 1989; 80(2):55-67.

52. Fotidar MR, Fotidar SN. 'Lotus' honey. Indian Bee $J$ 1945; 7:102.

53. Abbas T. Royal treat. Living in the Gulf, 1997, 50-1.

54. d'Agostino Barbaro A, La Rosa C, Zanelli C. Attivitantibatterica di mieliSiciliani [Antibacterial activity of Sicilian honeys]. Quad Nutr. 1961; 21(1, 2):30-44.

55. Buchner R. Vergleichende Untersuchungenber die antibakteriellen Wirkung von Bluten- und Honigtauhonigen [Comparative study of the antibacterial activities of 
honey]. SdwestdeutscherImker 1966; 18:240-1.

56. Christov G, Mladenov S. Propritsantimicrobiennes du miel [Antimicrobial properties of milk]. CR Acad Bulg Sci 1961; 14(3):303-6.

57. Efem SE. Recent advances in the management of Fournier's gangrene: preliminary observations. Surgery. 1993; 113(2):200-4.

58. Vardi A, Barzilay Z, Linder N, Cohen HA, Paret G, Barzilai A. Local application of honey for treatment of neonatal postoperative wound infection. Acta Paediatr. 1998; 87(4):429-32. 